\title{
Динаміка рівня фібриногену при артропластиці кульшового суглоба
}

\author{
В. І. Коломаченко
}

Харківська медична академія післядипломної освіти

\section{Dynamics of the fibrinogen level in the hip joint arthroplasty}

\author{
V. I. Kolomachenko
}

Kharkiv Medical Academy of Postgraduate Education

\begin{abstract}
Реферат
Мета. Аналіз динаміки рівня фібриногену (РФ) в періопераційному періоді у пацієнтів, яким виконували артропластику кульшового суглоба (КС).

Матеріали і методи. Первинна артропластика КС виконана у 136 пацієнтів у плановому порядку. Проаналізовано періопераційну динаміку РФ у залежності від методів інтраопераційної анестезії (IOA), післяопераційної аналгезії (ПОА), типу патології, статі пацієнтів.

Результати. РФ у крові у всіх пацієнтів перед операцією становив у середньому $(3,8 \pm 1,03)$ г/л. На 1 -шу добу після операції він дещо знизився - до $(3,3 \pm 0,65)$ г/л ( $=0,00016)$. На 3-тю добу РФ поступово підвищився та становив $(4,6 \pm 0,88)$ г/л ( $<<0,0001)$. На 7-му добу РФ у крові у всіх пацієнтів значно підвищився порівняно з вихідним рівнем та становив у середньому $(5,1 \pm 1,03)$ г/л ( $<0,0001)$. Найбільш вираженим було підвищення РФ після артропластики КС у пацієнтів, які після операції отримували системну опіоїдну аналгезію, порівняно з пацієнтами, яким застосовували пролонговану регіонарну аналгезію. РФ був вищим як перед, так і після операції у пацієнтів, яким операції виконували з приводу переломів, порівняно з пацієнтами, яким операції виконували з приводу коксартрозу в КС. За гендерною ознакою не виявлено істотної різниці в динаміці РФ у паціентів після артропластики КС.

Висновки. РФ знижується на 1-шу добу та підвищується на 3-тю і 7-му доби після артропластики КС, особливо у пацієнтів, які отримують системне знеболювання опіӧддами та оперовані з приводу переломів.

Ключові слова: артропластика кульшового суглоба; фібриноген; анестезія; аналгезія.

Objective. Analysis of the fibrinogen level (FL) dynamic in perioperative period in patients, to whom arthroplasty of the hip joint $(\mathrm{HJ})$ was done.

Materials and methods. Primary arthroplasty of $\mathrm{HJ}$ was conducted in 136 patients in a planned order. Perioperative dynamics of FL, depending on methods of intraoperative anesthesia, postoperative analgesia, the pathology type and the patients' gender, was analyzed.

Results. FL in the blood of all patients preoperatively have constituted $(3.8 \pm 1.03) \mathrm{g} / \mathrm{l}$ at average. On the first postoperative day it have lowered a bit of - to $(3.3 \pm 0.65) \mathrm{g} / \mathrm{l}(\mathrm{p}=0.00016)$. On the third day FL have raised gradually and constituted $(4.6 \pm 0.88)$ $\mathrm{g} / \mathrm{l}(\mathrm{p}<0.0001)$. On the seventh day FL in the blood of all patients have raised significantly, comparing with initial level and have constituted $(5.1 \pm 1.03) \mathrm{g} / \mathrm{l}$ at average $(\mathrm{p}<0.0001)$. Mostly pronounced FL rising after $\mathrm{HJ}$ arthroplasty was in those patients, who obtained opioid analgesia postoperatively, comparing with patients, to whom prolonged regional analgesia was performed. FL was higher preoperatively and postoperatively in the patients, to whom the operations were performed for fractures, comparing with the patients, to whom the operations were done for coxarthrosis in HJ. In accordance to the gender sign any essential difference in the FL dynamics in patients after arthroplasty of HJ was not revealed.

Conclusion. FL lowers on the first day and raises on the third and seventh days after the HJ arthroplasty, especially in patients, who obtained systemic anesthesia with opioids and were operated for fractures.

Keywords: the hip joint arthroplasty; fibrinogen; anesthesia; analgesia.
\end{abstract}

Abstract

Ендопротезування КС, яке є однією з найбільш поширених й успішних операцій у сучасній медицині, отримало назву «операція століття» [1], оскільки після цього втручання підвищується мобільність КС, зменшуються страждання пацієнта від болю та покращується якість його життя [2]. Артропластика КС супроводжується підвищеним ризиком розвитку тромбоемболічних ускладнень в післяопераційному періоді [3]. Для прогнозування таких ускладнень зазвичай використовують рівень Д-димеру в крові [4], хоча діагностична цінність цього показника останнім часом викликає сумніви, не кажучи вже про вартість такого аналізу [5]. Підвищення рівня Д-димеру в крові вка- зує на те, що тромб утворився та зазнав деградації, тобто є більш діагностичним, ніж прогностичним критерієм. Підвищення РФ у крові - це передумови утворення тромбів, тому цей показник слугує прогностичним фактором виникнення тромбоемболічних ускладнень. РФ у крові може бути більш доступним та досить інформативним маркером ризику тромбоемболічних ускладнень.

Для знеболення при ендопротезуванні КС застосовують як загальну, так і різні методики регіонарної анесте3iі. Дискусія про оптимальний метод анестезії та аналгезії щодо цієї операції триває вже багато десятиліть [6 - 8]. Проте лікування болю після такої операції часто є недо- 
статнім і немає згоди щодо пріоритетного методу знеболення [9 - 11]. Ефективне лікування післяопераційного болю залишається проблемою для лікарів, оскільки може впливати на результат хірургічного втручання. Якісне післяопераційне знеболення може не тільки знизити частоту розвитку хронічного болю, а й оптимізувати роботу м'язів та об'єм рухів у суглобі за рахунок зменшення тривалості іммобілізації [12]. 3 появою нових безпечних й ефективних регіонарних методів постає необхідність порівняти їх вплив на різні ланки коагуляції для прогнозування розвитку тромбоемболічних ускладнень після артропластики КС.

Мета дослідження: аналіз динаміки РФ у крові в періопераційному періоді у пацієнтів, яким виконували артропластику КС, а також вивчення впливу методів IОА, ПОА, типу патології, статі на динаміку цього показника у даних пацієнтів.

\section{Матеріали і методи дослідження}

Дослідження проведене щодо 136 пацієнтів, яким у Харківській обласній клінічній травматологічній лікарні у 2014 - 2016 рр. у плановому порядку виконано первинне ендопротезування КС (ASA II-III). Чоловіків було 52, жінок - 84. Середній вік хворих - $(64,2 \pm 13,7)$ року. Середня маса тіла - $(88,4 \pm 17,4)$ кг, зріст - $(167,7 \pm 9,2)$ см. На проведення дослідження отримано дозвіл етичного комітету Харківської медичної академії післядипломної освіти (протокол №5 від 23.05.2013 р.). Інформована згода отримана від усіх пацієнтів до проведення дослідження. Пацієнти випадковим чином розподілені на шість груп у залежності від методики IОА та ПОА (див. таблицю). У 1-й групі виконували спінальну анестезію на рівні L3-4 голкою G26 парамедіанним доступом у положенні лежачи на здоровому боці з уведенням 12 мг (2,4 мл) 0,5\% розчину бупівакаїну; після операції опіоїди вводили внутрішньом'язово. У 2-й групі після виконання аналогічної спінальної анестезії проводили катетеризацію паравертебрального простору із застосуванням набору Perifix 401 («BBraun», Німеччина) на рівні L3 на оперованій стороні з уведенням 20 мл 1\% розчину лідокаїну. В післяопераційному періоді в катетер вводили 0,25\% розчин бупівакаїну в 1-шу добу в темпі 3 мл/год, в наступні 3 - 4 доби - по 10 мл тричі за добу. У 3 -й групі виконували спінальноепідуральну анестезію на рівні L3-4, операцію проводили під спінальною анестезією, а в післяопераційному періоді в епідуральний катетер вводили 0,125\% розчин бупівакаїну в 1-шу добу в темпі 3 мл/год, в наступні 3 - 4 доби - по 10 мл тричі за добу. В 4-й групі виконували одноразову блокаду поперекового сплетення заднім доступом за Capdevila в комбінації з блокадою сідничного нерва за Labat-Moore 1\% розчином лідокаїну в дозі 800 мг 3 додаванням адреналіну 1:200 000 та дексаметазону 4 мг; після операції опіоїди вводили внутрішньом'язово. У 5-й групі виконували блокаду поперекового сплетення заднім доступом за Capdevila з наступною катетеризацією псоаскомпартменту в комбінації з каудальною блокадою з використанням 20 мл 0,75\% розчину ропівакаїну. Одразу після операції в катетер вводили 0,25\% розчин бупівакаїну в 1-шу добу в темпі 3 мл/год, в наступні 3 - 4 доби - по 10 мл тричі за добу. В 6-й групі застосовували загальну анестезію пропофолом по цільовій концентрації з фентанілом та атракуріумом у загальноприйнятих дозах з інтубацією трахеї та штучною вентиляцією легень; після операції опіоїди вводили внутрішньом'язово. У всіх пацієнтів як компоненти мультимодальної аналгезії застосовували ацетамінофен, нестероїдний протизапальний засіб та інфільтрацію шкіри і параартикулярних тканин місцевим анестетиком низької концентрації. Усі пацієнти отримували низькомолекулярні гепарини в профілактичних дозах для профілактики тромбоемболічних ускладнень починаючи з 1-ї доби після операції. Клінічних проявів тромбоемболічних ускладнень не було в жодного пацієнта. Статистично значущої різниці між групами за демографічними, гендерними показниками, діагнозами та тривалістю операції не виявлено.

Пацієнтів оперували із застосуванням чотирьох методів IOA: спінальної анестезії (група CA, n=68), блокад нервів (група БН, n=20), паравертебральної та каудальної анестезії (група ПВКА, n=27) та загальної анестезії (група 3A, n=21). Для післяопераційного знеболювання застосовані три варіанти аналгезії: опіоїди системно (група O, n=64), пролонгована паравертебральна аналгезія (група ПВА, n=51) та пролонгована епідуральна аналгезія (група ЕA, n=21). Хворих оперували з приводу наслідків коксартрозу (група К, n=72) та переломів (група П, n= 64) КС. Після операції хворих спонукали до ранньої фізичної активності, їм дозволяли ходити з ортопедичними опорними ходунками або на милицях з навантаженням на прооперовану кінцівку 70\% з першого дня після операції. Визначали РФ у венозній крові перед операцією та на 1,3-тю та 7-му добу після операції. Аналізували вплив методів IOA, ПОА, статі пацієнтів та характеру патології на динаміку РФ.

Статистичний аналіз проводили з використанням статистичного пакета Portable Statistica 8 (SPSS, v. 11.0 для Windows; SPSS Inc., Chicago, Illinois, USA). Непарні t-тести використані для аналізу відмінностей між групами, за рівень достовірності різниці вважали $\mathrm{p}<0,05$. Результати наведені у вигляді: середнє значення (M) \pm стандартне відхилення (б). Графіки будували для середніх значень параметрів у групах з встановленням довірчих інтервалів на рівні 95\%.

\section{Результати}

РФ у крові у всіх пацієнтів перед операцією становив у середньому $(3,8 \pm 1,03)$ г/л. На $1-ш у$ добу після операціі він дещо знизився - до $(3,3 \pm 0,65)$ г/л ( $=0,00016$ порівняно $з$ вихідним рівнем). Таке зниження РФ на 1-шу добу після операції можна пояснити операційною травмою та крововтратою, що призводять до порушення факторів згортання крові. На 3-тю добу РФ у крові поступово підвищився та становив $(4,6 \pm 0,88)$ г/л $(\mathrm{p}<0,0001$ порівняно з вихідним рівнем). На 7-му добу РФ у крові у всіх пацієнтів значно підвищився та становив у середньому $(5,1$ $\pm 1,03)$ г/л ( $<$ 0,0001 порівняно з вихідним рівнем).

РФ у крові до операції та на 1-шу добу після операції істотно не відрізнявся у всіх шести групах. На 3-тю добу після операції спостерігали підвищення РФ у крові паці- 


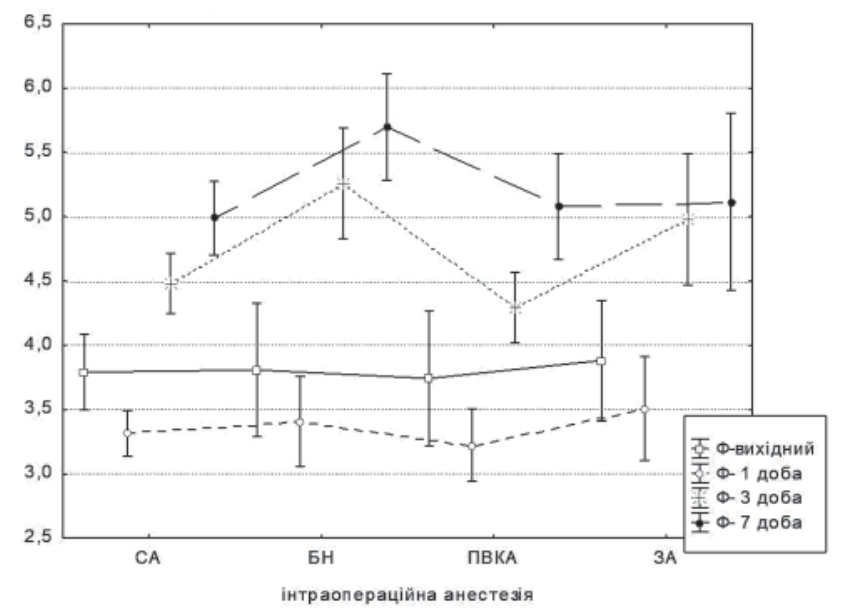

Puc. 1 .

Періоперащійна динаміка РФу крові (2/л) в залежності

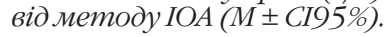

єнтів усіх шести груп порівняно з вихідним рівнем (р < 0,001), але в 4-й групі РФ був найвищим - $(5,3 \pm 0,87)$ г/л. РФ був вищим за нормальні значення також у $1-и ̆$ - (4,8 $\pm 1,24)$ г/л та 6-й - $(5,0 \pm 0,96)$ г/л групах. В інших трьох групах підвищення РФ було в межах норми: у 2-й та 3-й групах - $(4,3 \pm 0,62)$ г/л, у 5-й групі - $(4,3 \pm 0,57)$ г/л. На 7-му добу гіперфібриногенемію вище нормальних значень спостерігали у всіх шести групах, але найвищою вона була в 4-й групі - $(5,7 \pm 0,83)$ г/л, у всіх інших групах коливалась в межах 4,97 - 5,1 г/л.

Аналіз впливу методу IОА на динаміку РФ виявив таку картину (рис. 1). Вихідний РФ істотно не відрізнявся у пацієнтів, які отримували чотири варіанти анестезії (p < 0,05). На 1-шу добу після операції спостерігали деяке зниження РФ у всіх чотирьох групах у межах референтних значень. На 3-тю добу РФ був істотно вищим за вихідний рівень у всіх чотирьох групах, особливо у пацієнтів груп БН та ЗА. На 7-му добу у всіх чотирьох групах РФ продовжував зростати і був найвищим у групі БН.

Аналіз впливу методу ПОА на динаміку РФ виявив таку тенденцію (рис. 2). Вихідний РФ істотно не відрізнявся у пацієнтів, які отримували три варіанти аналгезіі (р < 0,05). У всіх трьох групах на 1-шу добу після операції РФ помірно знижувався і був у межах референтних значень. На 3-тю добу зростання РФ спостерігали у всіх трьох групах, причому найвищим РФ був у групі O, а в групах ПВА та ЕА його значення були на верхній межі норми. На 7му добу у всіх трьох групах РФ був значно вищим за вихідний рівень та виходив за межі нормальних значень.

Аналіз динаміки РФ у залежності від типу патології (коксартроз або перелом) виявив значні відмінності між цими групами (рис. 3). Загальну тенденцію істотно вищого РФ у пацієнтів, оперованих з приводу переломів, порівняно $з$ пацієнтами, оперованими з приводу коксартрозу, спостерігали на всіх етапах дослідження.

Аналіз періопераційної динаміки РФ у крові в залежності від статі пацієнтів не виявив істотних відмінностей цього показника. Більш високі показники РФ були у жінок порівняно з чоловіками на всіх етапах дослідження,

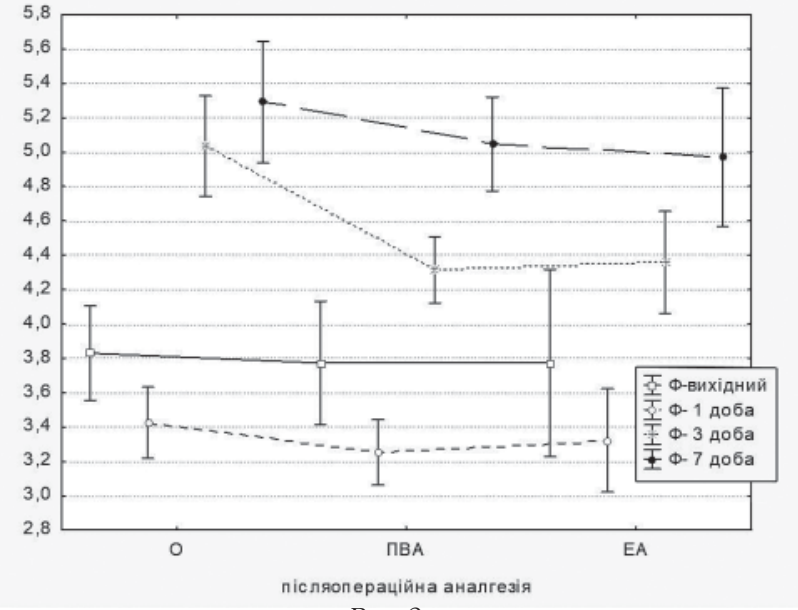

Puc. 2.

Періоперащійна динаміка РФукрові (2/л) в залежності

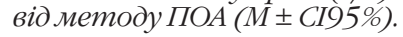

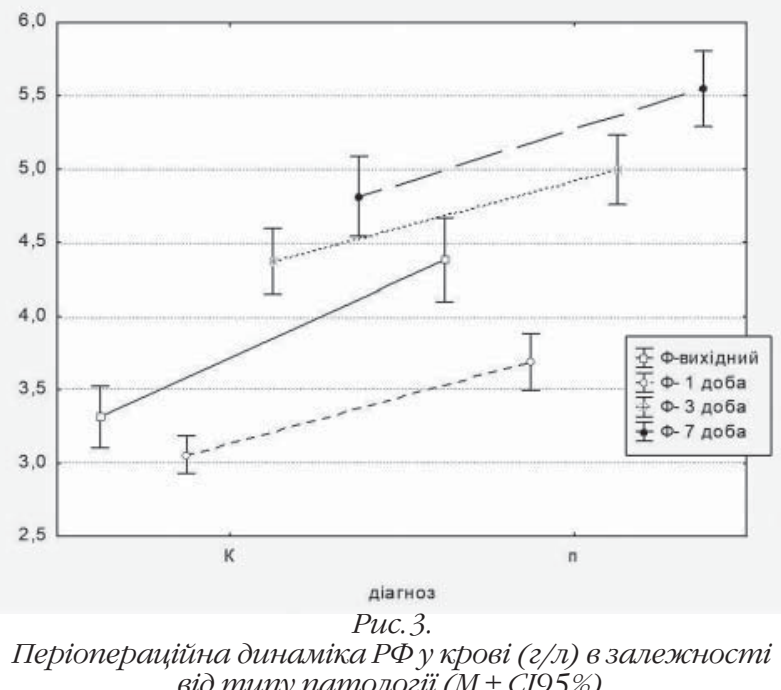
від типу патологіï ( $M \pm C I 95 \%)$.

але різниця була статистично незначущою ( $<$ 0,05). Як чоловіки, так і жінки мали однакову динаміку РФ у крові після артропластики КС: незначне зниження на 1-шу добу та підвищення на 3-тю та 7-му доби після операції.

\section{Обговорення}

Стан факторів коагуляції при застосуванні різних методів анестезії для артропластики КС вивчали в декількох дослідженнях. Зокрема, іспанські дослідники [13] не виявили впливу IOA на фактори коагуляції, але довели, що епідуральна аналгезія в післяопераційному періоді пом'якшує деякі маркери гіперкоагуляції. Вони порівнювали три варіанти анестезіі: спінальну та внутрішньовенну, спінально-епідуральну та загальну внутрішньовенну. Аналізували маркери коагуляції протягом 36 год після операції. Отримані нами результати динаміки РФ протягом тижня після операції узгоджуються з даними цих авторів та підтверджують перевагу регіонарних методів знеболювання, особливо в післяопераційному періоді. У пацієнтів, які отримували пролонговану епідуральну та па- 
равертебральну аналгезію після операції, менш виражено підвищувався РФ на 3-тю та 7-му доби після операції порівняно з пацієнтами, які отримували системне знеболювання опіоїдами.

T. Tetsunaga і співавтори [14] продемонстрували, що ризик виникнення тромбоемболічних ускладнень після артропластики КС вище у разі застосування після операції епідуральної та пацієнт-контрольованої системної опіоїдної аналгезії порівняно з пролонгованою блокадою стегнового нерва. У нашому дослідженні порівняння методів IОА виявило найвищий РФ у групі НБ, але це скоріше зумовлено тим, що ці пацієнти після операції отримували системне опоїдне знеболювання. Таку саму тенденцію спостерігали у пацієнтів, оперованих в умовах загальної анестезії, які після операції отримували знеболення опіоїдами.

M. Nakamura і співавтори [15] повідомили про те, що спінальна анестезія підвищуе ризик венозної тромбоемболії після артропластики КС на 48\% порівняно з комбінацією епідуральної та загальної анестезії. Наші дані демонструють більш потужний вплив на РФ методів післяопераційного знеболювання, ніж IOA, з перевагою пролонгованих регіонарних методик. Згідно з нашими результатами також необхідно моніторити стан коагуляції принаймні протягом тижня після артропластики КС.

Європейський гайдлайн з періопераційної профілактики венозного тромбоемболізму 2017 р. рекомендує рутинне застосування аспірину та низькомолекулярних гепаринів після артропластики КС [16]. Тривалість такої профілактики згідно з цим гайдлайном може становити від декількох ін'єкцій до чотирьох тижнів залежно від ступеня ризику тромбоемболічних ускладнень. Наші пацієнти отримували не аспірин, а нестероїдний протизапальний засіб, ацетамінофен та низькомолекулярний гепарин. Усі ці препарати можуть впливати на різні ланки коагуляції.

\section{Висновки}

1. У пацієнтів після артропластики КС РФ у крові дещо знижується на 1-шу добу після операції, а на 3-тю та 7 му доби істотно підвищується.

2. Найбільш вираженим є підвищення РФ після артропластики КС у пацієнтів, які після операції отримували системну опіоїдну аналгезію, порівняно з пацієнтами, яким застосовували пролонговану регіонарну аналгезію.

3. РФ є вищим як перед, так і після операції у пацієнтів, оперованих з приводу переломів, порівняно $з$ пацієнтами, оперованими з приводу коксартрозу в КС.

4. За гендерною ознакою істотної різниці в динаміці РФ у пацієнтів після артропластики КС не виявлено. У подальшій перспективі цікавим буде аналіз динаміки інших факторів коагуляції у даної категорії пацієнтів, а також вивчення взаємозв'язку між інцидентністю тромбоемболічних ускладнень та РФ.

\section{References}

1. Learmonth ID, Young C, Rorabeck C. The operation of the century: total hip replacement. Lancet. 2007;370:1508-19. doi: 10.1016/S01406736(07)60457-7.

2. Shan L, Shan B, Graham D, Saxena A. Total hip replacement: a systematic review and meta-analysis on mid-term quality of life. Osteoarthritis Cartilage. 2014;22:389-406. doi: 10.1016/j.joca.2013.12.006.

3. Bayley E, Brown S, Bhamber NS, Howard PW. Fatal pulmonary embolism following elective total hip arthroplasty: a 12-year study. Bone Joint J. 2016;98-B(5):585-8.

4. Adam SS, Key NS, Greenberg CS. D-dimer antigen: current concepts and future prospects. Blood. 2009.113(13):2878-87. PMID 19008457. doi:10.1182/blood-2008-06-165845.

5. Rafee A, Herlikar D, Gilbert R, Stockwell R, Mclauchlan G. D-Dimer in the diagnosis of deep vein thrombosis following total hip and knee replacement: a prospective study. Ann R Coll Surg Engl 2008;90:1236. doi 10.1308/003588408X.

6. Cozowicz C, Memtsoudis SG. General versus spinal anesthesia in joint arthroplasties. Ann Transl Med 2015;3(12):161. doi: 10.3978/j.issn.23055839.2015.06.11. http://dx.doi.org/10.3978/j.issn.2305-5839.2015.06.11.

7. Mickhael HK, Zekry J, Elrazek MA. Selective spinal anesthesia using low concentration bupivacaine and fentanyl versus ordinary bupivacaine as a prophylaxis against deep venous thrombosis in total hip replacement surgery. Ain-Shams Journal of Anesthesiology. 2016,09:393-7. DOI: 10.4103/1687-7934.189087.

8. Kehlet H, Aasvang EK. Regional or general anesthesia for fast-track hip and knee replacement - what is the evidence? [version 1; referees: 2 approved] F1000Research 2015, 4(F1000 Faculty Rev): 1449 (doi: 10.12688/f1000research.7100.1).

9. Opperer M, Danninger T, Stundner O, Memtsoudis SG. Perioperative outcomes and type of anesthesia in hip surgical patients: An evidence based review. World J Orthop 2014 July 18;5(3):336-43. doi:10.5312/ wjo.v5.i3.336.].

10. Johnson RL, Kopp SL, Burkle CM, Duncan CM, Jacob AK, Erwin PJ, Murad MH, Mantilla CB. Neuraxial vs general anaesthesia for total hip and total knee arthroplasty: a systematic review of comparative-effectiveness research. Br J Anaesth. 2016;116(2):163-76.

11. Greimel F, Maderbacher G, Zeman F, Grifka J, Meissner W, Benditz A. No clinical difference comparing general, regional, and combination anesthesia in hip arthroplasty: a multicenter cohort-study regarding perioperative pain management and patient satisfaction. J Arthroplasty. 2017;32(11):3429-33.

12. Jakobsson J, Johnson MZ. Perioperative regional anaesthesia and postoperative longer-term outcomes. F1000Research. 2016;5:F1000 Faculty Rev-2501. doi:10.12688/f1000research.9100.1.

13. de la Fuente Tornero E, Garutti Martínez I, Gutiérrez Tonal B, Rodríguez Huertas A, Chana Rodríguez F, Villanueva Martínez M, et al. Comparison of hemostatic markers under different techniques for anesthesia-analgesia in total hip or knee replacement. Rev Esp Anestesiol Reanim. 2010;57(6):333-40.

14. Tetsunaga T, Sato T, Shiota N, Tetsunaga T, Yoshida M, Okazaki Y, et al Comparison of continuous epidural analgesia, patient-controlled analgesia with morphine, and continuous three-in-one femoral nerve block on postoperative outcomes after total hip arthroplasty. Clinics in Orthopedic Surgery. 2015;7:164-70. http://dx.doi.org/10.4055/cios.2015.7.2.164.

15. Nakamura M, Kamei M, Bito S, Migita K, Miyata S, Kumagai K, et al. Spinal anesthesia increases the risk of venous thromboembolism in total arthroplasty. Secondary analysis of a J-PSVT cohort study on anesthesia. Medicine. 2017;96:18.

16. Jenny J-Y, Pabinger I, Samama CM. for the ESA VTE Guidelines Task Force. European guidelines on perioperative venous thromboembolism prophylaxis. Aspirin Eur J Anaesthesiol. 2017;34:1-7. 